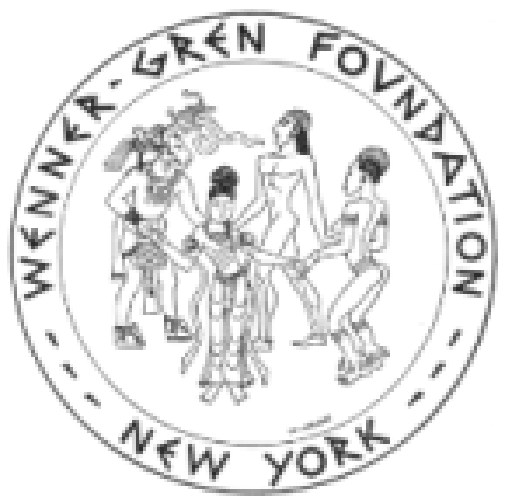

Misconstruals Miss the Mark: A Reply to El Guindi and Read

Author(s): Geoff Kushnick and Daniel M. T. Fessler

Reviewed work(s):

Source: Current Anthropology, Vol. 53, No. 1 (February 2012), pp. 136-137

Published by: The University of Chicago Press on behalf of Wenner-Gren Foundation for Anthropological

Research

Stable URL: http://www.jstor.org/stable/10.1086/663589

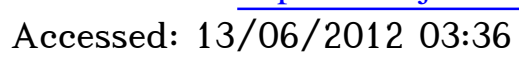

Your use of the JSTOR archive indicates your acceptance of the Terms \& Conditions of Use, available at http://www.jstor.org/page/info/about/policies/terms.jsp

JSTOR is a not-for-profit service that helps scholars, researchers, and students discover, use, and build upon a wide range of content in a trusted digital archive. We use information technology and tools to increase productivity and facilitate new forms of scholarship. For more information about JSTOR, please contact support@ jstor.org. 


\section{Misconstruals Miss the Mark}

\section{A Reply to El Guindi and Read}

\section{Geoff Kushnick and Daniel M. T. Fessler}

Department of Anthropology, University of Washington, Seattle, Washington 98195-3100, U.S.A. (kushnick@u .washington.edu)/Center for Behavior, Evolution, and Culture, Department of Anthropology, 341 Haines Hall, University of California, Los Angeles, California 90095-1553, U.S.A. 21 X 11

El Guindi and Read criticize our (Kushnick and Fessler 2011) exploration of Westermarckian phenomena on the grounds that (1) evidence in support of the Westermarck hypothesis $(\mathrm{WH})$ is weak and (2) our characterization of Karo marriage preferences is misguided. Their critique, however, suffers from a selective use of the literature, a misconstrual of the hypothesis at issue, and factual errors.

El Guindi and Read's first position presumes that human psychology lacks evolved inbreeding-avoidance mechanisms - in their words, "Why should there be a natural aversion among siblings?" While this was a plausible question when Westermarck's contemporaries challenged him over a century ago, it is an astounding position to adopt today. Voluminous evidence documents such mechanisms in other species (e.g., Pusey 2004), findings paralleled by psychological research in humans independent of the natural experiments that El Guindi and Read problematize (Lieberman et al. 2003, 2007; Fessler and Navarette 2004). Moreover, the evidence regarding natural experiments is far less equivocal than El Guindi and Read suggest. Humans' detection of biological relatedness relies on a hierarchy of cues (Lieberman et al. 2007). When natural experiments are revisited in light of this (Lieberman 2009; Lieberman and Lobel 2012), the evidence in favor of the WH is substantially strengthened-indeed, contrary to the impression created by El Guindi and Read's out-of-context quotation, Rantala and Marcinkowska (2011) made exactly this point in their review.

El Guindi and Read discuss the prevalence of cousin marriage in Qatar, and point to Henrich and Henrich's (2007) work among Chaldeans, as evidence of "the desirability of marriage among close kin." However, the authors are (1) conflating a cultural preference for cousin marriage with the subjective experience of sexual attraction and (2) failing to grasp the role of cosocialization in the $\mathrm{WH}$. There is nothing new in the observation that norms for cousin marriage are common-indeed, it was precisely this that motivated Westermarck's original work, as the conflict he observed was between a prescription for cousin marriage and a subjective aversion resulting from cosocialization. Correspondingly, al-

(C) 2012 by The Wenner-Gren Foundation for Anthropological Research. All rights reserved. 0011-3204/2012/5301-0013\$10.00. DOI: 10.1086/ 663589 though the Henrichs observed many cases of first-cousin marriage, none were among cousins who had been cosocialized (J. Henrich, personal communication, 2011). El Guindi and Read's statement that "cousins in many traditional Arab social systems live close to one another, engage in daily interactions, are considered to be ideal spouses, and form stable marriages" fails to distinguish between simple interaction and cosocialization. Adducing observations of successful cousin marriage in the absence of cosocialization reveals a fundamental lack of understanding of the $\mathrm{WH}$, as the success of such marriages is exactly what the WH predicts.

El Guindi and Read's second position is to take exception to our "assumptions" about Karo marriage. First, they claim that we have "asserted without presenting evidence" the existence of "a folk model of aversion purportedly spreading among the people." In so characterizing our paper, they simultaneously overstate our claim and understate our evidence. As we noted, our second model, incorporating realistic demographic assumptions, was used to explore the "possibility" that a folk model explanation applies. We concluded that rates of cosocialization "seem sufficiently high to potentially generate and maintain the counternormative folk model" (Kushnick and Fessler 2011:446). We thus proposed that the necessary preconditions exist for a folk model stemming from the Westermarck effect-nothing more.

Second, El Guindi and Read claim that the observed rate of impal marriage (3.5\%) is exactly as expected and thus does not support the inference that a Westermarck effect is at play. They base this on a misguided application of Kunstadter et al.'s (1963) simulation that predicts rates of matrilateral crosscousin marriages (first cousins only) at $25 \%-30 \%$ with a cultural preference, and $1 \%-2 \%$ in the absence of one (not $3 \%-$ $4 \%$ as claimed by El Guindi and Read, a figure concocted by doubling the prediction to include second cousins). However, impal marriages are clearly culturally preferred. For instance, Kipp (1983:130) states that "the most desirable marriages are between impal.” Singarimbun's (1975) statement, quoted by El Guindi and Read, that Karo do not "encourage these forms of marriage above all others" derives from Singarimbun's observation that impal marriages rarely occur. In short, El Guindi and Read have mistaken the explanandum for the explanans. Even if the cultural preference is weaker than Kipp claims, Kunstadter et al.'s (1963) figures still do not support El Guindi and Read's position, as their low-end prediction is for marriages that occur "by accident" when a preference is completely lacking-which is clearly not the case. Contrary to El Guindi and Read's assertion, the predicted rate for firstcousin impal marriage in the absence of a Westermarck effect is far higher than 1\%-2\% (and even higher if second cousins are included). That impal marriage is nonetheless rare is thus consonant with reports of a subjective aversion that runs counter to the normative preference-the hallmark of Westermarckian natural experiments. 


\section{References Cited}

Fessler, Daniel M.T., and C. David Navarrete. 2004. Third-party attitudes toward sibling incest: evidence for Westermarck's hypotheses. Evolution and Human Behavior 25:277-294.

Henrich, Natalie, and Joseph Henrich. 2007. Why humans cooperate a cultural and evolutionary explanation. Oxford: Oxford University Press.

Kipp, Rita Smith. 1983. A political system of highland Sumatra, or rethinking Edmund Leach. In Beyond Samosir: recent studies of th Batak peoples of North Sumatra. Rita Smith Kipp and Richard D. Kipp, eds. Pp. 125-138. Athens: Ohio University Press.

$\rightarrow$ Kunstadter, Peter, Roald Buhler, Frederick F. Stephan, and Charles F. Westoff. 1963. Demographic variability and preferential marriage patterns. American Journal of Physical Anthropology 21:511-519.

$\rightarrow$ Kushnick, Geoff, and Daniel M. T. Fessler. 2011. Karo Batak cousin marriage, cosocialization, and the Westermarck hypothesis. Current Anthropology 52(3):443-448.

$\rightarrow$ Lieberman, Debra. 2009. Rethinking the Taiwanese minor marriage data: evidence the mind uses multiple kinship cures to regulate inbreeding avoidance. Evolution and Human Behavior 30:153-160.

$\rightarrow$ Lieberman, Debra, and Thalma Lobel. 2012. Kinship on the kibbutz: coresidence duration predicts altruism, personal sexual aversions, and moral attitudes among communally reared peers. Evolution and Human Behavior 33(1):26-34.

Lieberman, Debra, John Tooby, and Leda Cosmides. 2003. Does morality have a biological basis? an empirical test of the factors governing moral sentiments regarding incest. Proceedings of the Royal Society B: Biological Sciences 270:819-826.

. 2007. The architecture of human kin detection. Nature 445: 727-731.

Pusey, Anne. 2004. Inbreeding avoidance in primates. In Inbreeding, incest, and the incest taboo. Arthur P. Wolf and William H. Durham, eds. Pp. 61-75. Stanford, CA: Stanford University Press.

Rantala, Markus J., and Urszula W. Marcinkowska. 2011. The role of sexual imprinting and the Westermarck effect in mate choice in humans. Behavioral Ecology and Sociobiology 65:859-873.

Singarimbun, Masri. 1975. Kinship, descent, and alliance among the Karo Batak. Berkeley: University of California Press. 